\title{
Pemanfaatan WhatsApp dalam Pemantauan Pola Tumbuh Kembang Bayi dan Balita Masa Pandemi Covid-19
}

\author{
Islah Wahyuni \\ Email: islah fattan@yahoo.co.id \\ Prodi S1 dan Profesi Kebidanan, STTIKes Payung Negeri Pekanbaru, Indonesia \\ Jl. Tamtama No.6 Kelurahan Labuh Baru kecamatan Payung sekaki Pekanbaru Riau \\ Telp. (0761) 885214
}

\begin{abstract}
Abstrak:
1000 hari pertama usia anak menentukan kesehatan mereka kedepannya. Pemantauan tumbuh kembang pada bayi dan balita bertujuan menemukan secara dini masalah pertumbuhan pada bayi dan balita. Akibat masa pandemic covid-19 banyak posyandu yang tutup dan pelayanan pemantauan pertumbuhan dan perkembangan bayi balita dan anak seolah terabaikan. Tujuan kegiatan ini dalam mengidentifikasi masalah pertumbuhan dan perkembangan bayi balita di saat kegiatan imunisasi di Praktek Bidan Swasta pada masa pandemic.Metode pelaksanaan kegiatan ini adalah memberikan KIE kelompok, pengukuran antropometri dan sharing WhatsApp grup. Hasil kegiatan adalah ditemukan dua orang bayi yang mengalami keterlambatan pertumbuhan dan sudah diberikan edukasi dan tindakan pemantauan berat badan dan panjang badan selama 4 minggu berturut-turut dengan perubahan kenaikan Berat Badan dan Panjang Badan mereka. Penggunaan WhatsApp sangat efektif dalam membantu meningkatkan pemahaman terhadap pola pertumbuhan bayi serta teknik pemberian Makanan Pendamping ASI.
\end{abstract}

Kata Kunci: whatsapp; tumbuh kembang bayi balita; pandemic covid-19.

\begin{abstract}
:
The first 1000 days of a child's life determine their future health. Growth monitoring in infants and toddlers aims to find early growth problems in infants and toddlers. As a result of the Covid-19 pandemic, many posyandu were closed and services for monitoring the growth and development of infants and children were neglected. The purpose of this activity is to identify growth and development problems for infants under five during immunization activities at the Private Midwife Practice during the pandemic. The method of implementing this activity is to provide group IEC, anthropometric measurements and group WhatsApp sharing. The result of the activity was that two babies who experienced growth delays had been given education and monitoring of body weight and length for 4 consecutive weeks with changes in their weight gain and length. The use of WhatsApp is very effective in helping improve understanding of baby growth patterns and complementary breastfeeding.
\end{abstract}

Keywords: whatsapp; infant growth and development; covid-19 pandemic. 


\section{Pendahuluan}

Masa 1000 hari pertama usia anak menentukan kesehatan mereka kedepannya. Pemantauan tumbuh kembang pada bayi dan balita bertujuan menemukan secara dini masalah pertumbuhan pada bayi dan balita ${ }^{(1)}$ Akibat masa pandemic covid-19 banyak posyandu yang tutup dan pelayanan pemantauan pertumbuhan dan perkembangan bayi balita dan anak seolah terabaikan $^{(18)}$

Wabah pandemic covid-19 sangat merugikan masyarakat dalam bidang kesehatan, mereka dibatasi dalam berkunjung ke tempat pelayanan kesehatan, adanya ketakutan dan kecemasan masyarakat untuk tertular virus covid-19 $9^{(2)}$. Penerapan protocol kesehatan dengan PHBS sangat ketat dan diterapkan betul saat masyarakat berkunjung ke fasilitas pelayanan kesehatan, sehingga sangat disarankan agar masyarakat membatasi kunjungan ke rumah sakit, puskesmas atau tempat kesehatan lainya, dan jika tidak terpaksa betul kondisinya maka diharapkan agar membuat janji (appointment)dengan petugas kesehatan hanya melalui media social seperti telepon, sms, dan lainnya utnuk berkonsultasi mengenai kesehatan mereka. ${ }^{(3)}$

Dalam mencegah penularan virus Covid-19 selama masa pandemic ini, maka kegiatan komunikasi dan sistem koordinasi antar orang dilakukan melalui media Zoom, Hangouts, Google Meets, WhatsApp dan sejenisnya, sehingga masih dapat memantau kegiatan antar suatu kelompok ${ }^{(4)}$

Perkembangan Revolusi 4.0 merupakan masa perubahan revolusi industry keempat dengan memanfaatkan teknologi dalam setiap kehidupan dan aktivitas kita, sehingga dapat merubah cara pandang, pola aktivitas dan bekerja antara satu sama lainnya. Perubahan transformasi ini memicu kepada perubahan positif dalam pelayanan kesehatan dewasa ini ${ }^{(5)}$.

Salah satu bentuk perkembangan Revolusi 4.0 adalah dengan Penggunaan telepon genggam pintar (smartphone) sudah merata diseluruh masyarakat kita ${ }^{(6)}$, yang sangat berperan penting sekali dimasa pandemic ini, selama work from home (WFH) dan stay at home, handphone menjadi andalan masyarakat dalam memenuhi kebutuhan mereka dalam segala informasi dan kesehatan yang mereka butuhkan dengan berselancar didunia maya dan memanfaaatkan aplikasi lainnya dalam menjalin komunikasi dengan provider kesehatan selama masa pandemic ini ${ }^{(4)}$.

Begitu juga peningkatan kualitas pelayanan kesehatan dalam memberikan pendidikan bagi masyarakat akan mampu membantu mencapai pemerataaan kesehatan pada masyarakat yang terpencil sekaligus, akibat perkembangan era revolusi industri $4.0 \mathrm{ini}^{(7)}$.

Media social Whatsapp dewasa ini banyak digunakan sebagai media komunikasi bagi penggunanya, dikarenakan kemudahan fitur dan layanannya. Dapat dipakai oleh berbagai kelompok dan golongan, sehingga pesan singkat melalui SMS berbayar sekarang dapat digantikan oleh Whatsapp ${ }^{(8)}$. Pengiriman pesan cepat dan bisa berbalas cepat dalam satu layar percakapan chat antara si penggunanya. Pengiriman pesan suara, gambar dan video begitu jernih dan jelas, sehingga memungkinkan kepuasan pelanggan dalam memanfaatkan media Whatsapp dalam menjalin 


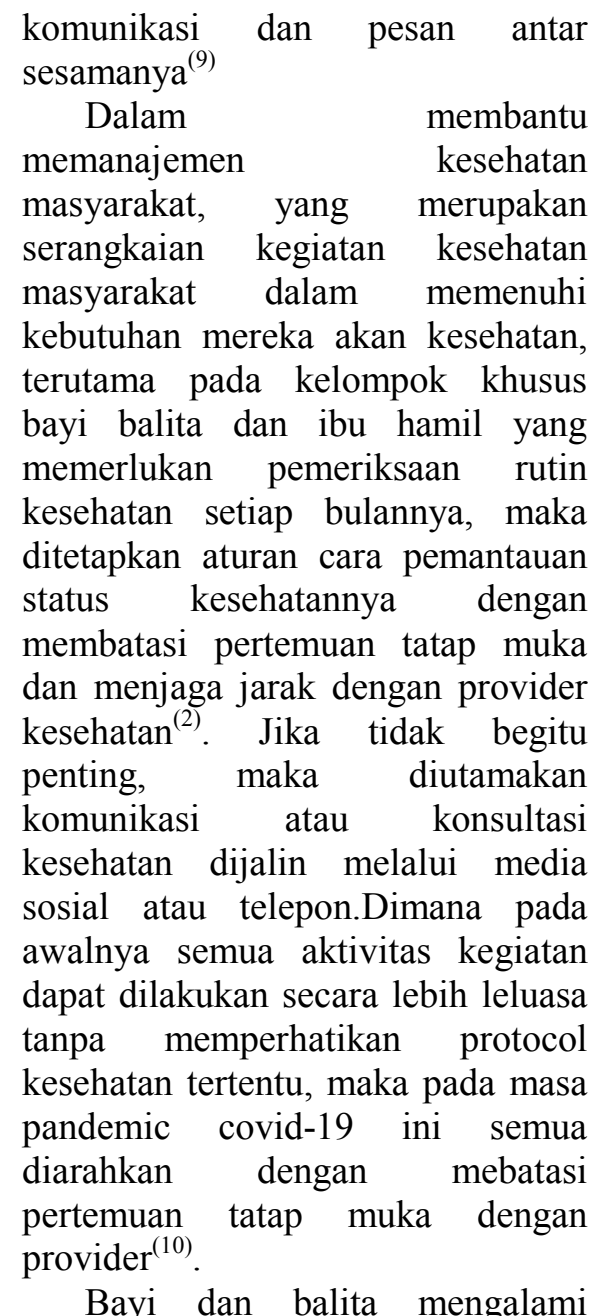
pertumbuhan dan perkembangan yang sangat krusial dipantau dalam dua tahun pertama kehidupan mereka, dalam masa ini ada bahaya Stunting dan keterlambatan pertumbuhan (delayed growth) dan perkembangan bayi balita yang sangat rentan untuk diamati dan dipantau oleh bidan sebagai provider $^{(4)}$. Kegiatan posyandu yang dibatasi dalam masa pandemic membuat perkembangan dan kenaikan berat badan serta panjang bayi balita menjadi tidak terpantau dengan baik, sehingga diperlukan upaya dalam melakukan pemantauan tersebut baik dilakukan melalui kontak langsung tatap muka langsung, maupun dengan media handphone yang dimanfaatkan melalui WhatsApp Group.

Di area PraktekMandiriBidan Islah Wahyuni Desa Kualu, tetap dilaksanakan kegiatan posyandu setiap bulan dengan menerapkan protocol kesehatan yang sudah ditetapkan, dengan menjaga jarak, menggunakan masker dan faceshield, sewaktu bayi dan balita dibawaberkunjung ke klinik. Pada faktanyanya dimasa pandemic ini ternyata didapatkan data bahwa ada ibu post partum yang pergi mengunjungi bidan dengan berat badan bayinya naik hanya 3,5 ons dari berat badan lahir setelah 1,5 bulan kelahiran bayinya. Dan ada juga bayi usia 6 bulan mengalami 2 kali arah pertumbuhan di KMS yang datar (gagal tumbuh).

TimPKM STIKes Payung Negeri merasa perlunya kegiatan PKM ini dilakukan, dikarenakan pentingnya 1000 hari kehidupan bayi dan balita, maka dalam kegiatan PKM ini, pemantauan tumbuh kembang bayi dan balita dilakukan melalui pertemuan offlinetatap muka dan pertemuan online melalui WhatsAppdilakukan guna memotivasi dan mensupport orangtua dalam melakukan pemantauan tumbuh kembang anaknya dalam masa pandemic yang serba terbatas ini.

\section{Metode}

Pelaksanaan pengabdian masyarakat merupakan kegiatan pemberian bantuan dan pelayanan secara Cuma-Cuma maupun memandirikan masyarakat yang dilakukan oleh Dosen (baik secara pe-orangan maupun kelompok), Laboratorium, Jurusan, serta Pusat Penelitian, perguruan tinggijuga dapat melaksanakannya sesuai dengan bentuk kegiatan pengabdian yang relevan ${ }^{(11)}$ 
Kegiatan initelah kami lakukan dengan dua cara, yaitu 1) Offline tatap muka langsung dan 2) secara online dengan memanfaatkan media WhatsApp. Transfer pengetahuan dan penilaian indicator pertumbuhan bayi balita dengan pengukuran antropometri (LIKA, BB, PB, Umur) dilakukan saat tatap muka langsung secara personal dan kelompok kecil, dan system follow up dilakukan dalam media WhatsApp grup.

Tahapan kegiatan:

1) Mempersiapkan program Pemantauan Tumbuh Kembang Bayi Balita, meliputi survey, koordinasi kelompok sasaran, mengumpulkan informasi dan nomor telepon, pengurusan izin dan persiapan bahan kegiatan PKM.

2) memberikan penyuluhan dan edukasi saat pelayanan posyandu dan imunisasi tentang topiktumbuh kembang dan MPASI yang mempengaruhinya secara offline maupun online.

3) Follow up dan mengikuti kasus perkembangan $\mathrm{BB}$ bayi yang bermasalah selama 4 minggu.

\section{Hasil dan pembahasan}

Kegiatan Pengabdian masyarakat ini telah dilakukan sejak 7 Oktober sampai 7 Desember 2020 di Praktek Bidan Mandiri Islah wahyuni, dengan jumlah peserta yang terpantau dalam 2 bulan ini adalah 20 orang dan 2 bayi ditemukan dengan gangguan pertumbuhan/kenaikan Berat Badan di bulan Oktober 2020 yang perkembangannya kami pantau selama 4 minggu berturut turut, dan memperlihatkan perubahan signifikan.

Teknis pelaksanaan pelayanan secara offline ditetapkan janjian penetapan jadwal dari jam $4-6$ sore, dilakukan penilaian indikator Antropometri bayi balita yang berkunjung, sebelum dilakukan penyuluhan dan edukasi kepada orangtua mereka. Edukasi yang diberikan menggunakan media leaflet dan gambar lembar balik tentang pola pertumbuhan anak dan penjelasan KMS terkait kenaikan berat badan dan tinggi badan bayi balita. Disamping itu digunakan media gizi seimbang berupa video tentang pembuatan dan pemberian MP-ASI yang tepat sesuai usia anak.

Dan secara online semua ibu yang memiliki bayi balita yang sudah terdata dibina melalui WhatsAppgrup, membentuk kedekatan hubungan dan kepercayaan ibu terhadap tenaga kesehatan, serta membuka cakrawala berfikir mereka terhadap pentingnya pengamatan dan penilaian pertumbuhan dan perkembangan anak mereka, terjadinya diskusi dan sharing yang melibatkan orang yang ada dalam grup untuk berkontribusi dalam media percakapan yang sengaja dibuat guna memfasilitasi ibu-ibu dalam memahami kebutuhan bayi balita mereka selama masa pandemic ini.

Pada bayi yang ditemukan mengalami delayed growthtersebut, tim PKM melakukan pengkajian (deep interview) dan analisa mendalam terhadap faktor-faktor yang menyebabkan gangguan pertumbuhan/kenaikan berat badan bayi seperti pengkajian tentang riwayat dan kualitas asupan nutrisi ibu selama masa menyusui bayinya, serta mendiskusikan rencana penatalaksanaan terhadap masalah bayi mereka ${ }^{(12)}$.

Adanya feed back dan follow up terhadap dua bayi yang mengalami delayed growth selama masa pertumbuhan mereka yang dipantau 
selama empat minggu berturut-turut, menjadikan kepuasan tersendiri bagi ibu dan keluarga karena mendapatkan pencerahan dan pengetahuan bahwa factor delayed growth disebabkan dari asupan nutrisi ibu. ${ }^{(13)}$ Asupan nutrisi ibu selama ini rendah protein hewani, hal ini dapat akibat pengaruh social budaya mereka yang membatasi asupan makanan yang mengandung protein hewani, karena khawatir luka jalan lahir gatal dan lama sembuhnya, sehingga dominan asupan nutrisi diperoleh dari protein nabati saja (sayur-sayuran saja) ${ }^{(14)}$. Akibatnya penambahan berat badan anaknya sedikit sekali danlambat, sehingga bayi mengalami status gizi kurang untuk usianya saat ini.

Dibawah ini diperoleh hasil rekapitulasi data ibu-ibu peserta PKM, meliputi karakteristik ibu, status gizi bayi balita, dan respon kepuasan orangtua dalam penggunaan WhatsApp dalam pemantauan tumbuh kembang bayi balita sebagai berikut:

\section{a. Karakteristik orangtua bayi balita}

Tabel 1. Distribusi Frekuensi Karakteristik Responden di BPM Islah Wahyuni

\begin{tabular}{|c|c|c|c|c|}
\hline No & Perilaku & $\mathbf{N}$ & Jumlah & Persentase (\%) \\
\hline \multirow[t]{4}{*}{1} & Umur & 20 & & \\
\hline & $-\quad<20$ & & 1 & 5 \\
\hline & $-\quad 20-35$ & & 16 & 80 \\
\hline & $-\quad 35-45$ & & 3 & 15 \\
\hline \multirow[t]{4}{*}{2} & Pendidikan: & 20 & & \\
\hline & - $\quad$ Pendidikan Dasar & & 6 & 30 \\
\hline & - $\quad$ Pendidikan Menengah & & 12 & 60 \\
\hline & $\begin{array}{ll}- & \text { Pendidikan Tinggi }\end{array}$ & & 2 & 10 \\
\hline \multirow[t]{3}{*}{3} & Pekerjaan : & 20 & & \\
\hline & - $\quad$ Bekerja & & 3 & 15 \\
\hline & - $\quad$ Tidak Bekerja & & 17 & 85 \\
\hline
\end{tabular}

Berdasarkan Tabel 1 dapat diketahui bahwa, mayoritas peserta di BPM Islah Wahyuni Tahun 2020 berdasarkan umur mayoritas 20-35 tahun sebanyak 16 orang $(80 \%)$, mayoritas berpendidikan Menengah sebanyak 12 orang (60\%), mayoritas tidak bekerja sebanyak 17 orang 


\section{b. Hasil pemantauan Antropometri bayi Balita}

Tabel 2. Distribusi Frekuensi hasil pemantauan Antropometri bayi balita di BPM Islah Wahyuni

\begin{tabular}{|c|c|c|c|c|}
\hline No & Perilaku & $\mathbf{N}$ & Jumlah & Persentase (\%) \\
\hline \multirow[t]{3}{*}{1} & LIKA & 20 & & \\
\hline & - $\quad$ Sesuai umur & & 20 & 100 \\
\hline & $\begin{array}{ll} & \text { Tidak sesuai umur }\end{array}$ & & 0 & 0 \\
\hline \multirow[t]{3}{*}{2} & BB/Umur & 20 & & \\
\hline & - $\quad$ Normal/naik & & 18 & 90 \\
\hline & - $\quad$ Datar/tidak naik & & 2 & 10 \\
\hline \multirow[t]{3}{*}{3} & $\mathrm{BB} / \mathrm{TB}$ & 20 & & \\
\hline & - $\quad$ Stunting & & 0 & 0 \\
\hline & - Normal & & 20 & 100 \\
\hline
\end{tabular}

Berdasarkan Tabel 2 dapat diketahui bahwa, mayoritas peserta di BPM Islah Wahyuni Tahun 2020 berdasarkan LIKA semuanyasesuai umur sebanyak 20 orang $(100 \%)$, mayoritas $\mathrm{BB} / \mathrm{U}$ naik sebanyak 18 orang $(60 \%)$, semua peserta BB/TB normal sebanyak 20 orang $(100 \%)$.

\section{c. Respon kepuasan orangtua dalam penggunaan WhatsApp dalam} pemantauan tumbuh kembang bayi balita

Tabel 3. Distribusi Frekuensi hasil respon kepuasan orangtua dalam penggunaan WhatsApp dalam pemantauan tumbuh kembang bayi balita di BPM Islah Wahyuni

\begin{tabular}{llccc}
\hline No & Perilaku & N & Jumlah & Persentase (\%) \\
\hline $\mathbf{1}$ & Tk. kepuasan & 20 & & \\
\hline & $-\quad$ Puas & & 100 \\
\hline & $-\quad$ Tidak puas & 0 & 0 \\
\hline $\mathbf{2}$ & Tk. Keaktifan dalam WA & 20 & & 85 \\
\hline & - Aktif & & 17 & 15 \\
\hline & - Pasif & 3 & \\
\hline
\end{tabular}


Berdasarkan Tabel 1.3 dapat diketahui bahwa, mayoritas peserta di BPM Islah Wahyuni Tahun 2020 berdasarkan tingkat kepuasan pelayanan dalam WAG semuanya merasa puas sebanyak 20 orang $(100 \%)$, mayoritas tingkat keaktifan peserta dalam WAG adalah aktif sebanyak 17 orang (85\%).

\section{Pembahasan :}

Asuhan kebidanan pada masa pandemic ini merupakan asuhan kebidanan difokuskan untuk upaya preventif $^{(2)}$. Resiko infeksi dan penularan penyakit serta terjangkiti penyakit tentunya sangat memungkinkan terjadi pada kelompok bayi dan balita yang memiliki imunitas tubuh yang belum begitu kuat ${ }^{(15)}$, untuk itu perlu tindakan pemantauan dan penilaian pola tumbuh kembang bayi dan balita yang dapat mencegah terjadinya delayed growth atau faltering growth pada bayi dan balita, tentunya akan membuat masalah pada masa 1000 hari pertama kehidupan mereka, dan keterlambatan dalam pertumbuhan otak anak akan menurunkan daya tangkap dan kecerdasan anak dimasa depannya $^{(16)}$.

Pengetahuan orangtua sangat berpengaruh dalam pemantauan tumbuh kembang anak mereka, sehingga pengetahuan yang dimiliki akan membuat orangtua lebih peka dan peduli dengan kondisi kesehatan dan tumbuh kembang anaknya ${ }^{(17)}$. Peran orangtua dalam pola asuh, asih dan asah sangat menentukan masa depan anaknya, dimana pola pengasuhan akan membantu proses laju pertumbuhan dan perkembangan anak sejak lahir sampai kelak dia dewasa. Orangtua akan menanamkan nilai-nilai pendidikan dan transfer of knowledge terhadap anak-anaknya dalam menjaga kesehatan mereka dimasa datang ${ }^{(18)}$.

Seiring wabah pandemic covid19 ini menjadikan banyaknya keterbatasan pada orangtua dalam mendapatkan pengetahuan langsung dari tenaga kesehatan $^{(19)}$, akibat keterbatasan penerapan protocol kesehatan yang mengharuskan social distancing dan fysical distancing serta penerapan $3 \mathrm{M}$ (menjaga jarak, memakai masker dan mencuci tangan) menjadikan orangtua takut dan cemas untuk membawa anak mereka ke posyandu atau ke puskesmas, sehingga pola tumbuh kembang anak yang sudah mereka lahirkan menjadi tidak terpantau dengan maksimal ${ }^{(4)(20)}$.

Penerapan pembatasan pertemuan secara offline tatap muka dengan tenaga kesehatan mengharuskan adanya inovasi usaha promotif dan preventif dalam bidang layanan kesehatan, yang mesti dilakukan oleh semua tenaga kesehatan yang memberikan pelayanan kepada masyarakat, sehingga penggunaan smartphone menjadi pilihan utama dan penting yang bisa sangat membantu pemantauan tumbuh kembang anak walaupun secara online ${ }^{(10)}$, namun semua bisa dilakukan dengan baik dengan keberadaan WhatsApp grup yang terbentuk dalam rangka menjangkau pelayanan kesehatan 
era pandemic ini secara diskusi dan sharingonline terkait masalah tumbuh kembang bayi balita dan masalah-masalah yang muncul dalam periode ini serta bagaimana cara pemberian MP-ASI pada bayi balita mereka dan masalah lainnya seperti stress dan kecemasan pada masa pandemic ini ${ }^{(4)(21)}$

Penelitian

Peristianto, Anggawijayanto, 2020 bahwa pengelolaan stress dengan media komunikasi onlineseperti aplikasi WhatsApp dapat berdampak positif terhadap adaptasi mereka dalam menghadapi pandemic covid-19 ini. Terdapat Enam langkah pengelolaan stres yang dianjurkannya pada masyarakatKecamatan Sewon, Kabupaten Bantul secara online, antara lain 1) mencari informasi mengenai covid-19 dari sumber yang terpercaya, 2) membatasi akses internet, 3) tetap menjalin hubungan dan komunikasi dengan orang-orang yang terkasih, 4) mengelola perasaan diri sendiri, 5) menyusun rutinitas harian, dan 6) rajin melakukan relaksasi pernapasan $^{(4)}$

Senada dengan Penelitian Yusmita, Larisu, Saidin, 2014 bahwa banyak manfaat penggunaan WhatsApp dalam komunikasi antar individu dalam keseharian, dimana WhatsApp sebagai media sosial dapat menjadi tempat untuk mendapatkan kemudahan berkomunikasi, menambah teman dan meningkatkan eksistensi diri. Para pengguna WhatsApp memiliki motif mengikuti perkembangan zaman dan mereka juga menggunakan whatsapp sebagai tempat berbagi informasi, berita, atau organisasi yang mereka lakukan. Komunikasi yang terjalin setelah menggunakan WhatsAp pmenjadi lebih lancar, dan mudah untuk mengenali teman dekatnya. ${ }^{(9)}$

Budaya sosial yang kuat pada masyarakat Indonesia dalam menjalin hubungan relasi. Absurditas pada masa pandemi covid-19menjadikan pertemuan dan perjumpaan masyarakat secara langsung tatap muka menjadi moment yang langka dan terbatas. Pertemuan dengan orang-orang yang mereka cintai dapat dilakukan melalui proses virtual saja,mereka hanya bisa pasrah dan harus beradaptasi menerima kenyataan ini. Hal ini menjadikan proses tatap muka pertemuan secaralangsung memiliki nilai kehidupan yang tinggi dan penting sekali dalam kehidupan sehari-hari ${ }^{(4)}$.

Penelitian Trisnani, 2017 tentang Penelitian Pemanfaatan WhatsApp Sebagai Media Komunikasi Dan Kepuasan Dalam Penyampaian Pesan dikalangan tokoh masyarakat diketahui bahwa WhatsApp paling dominan digunakan. Pada saat ini, WhatsApp telah dimanfaatkan oleh tokoh masyarakat untuk berkomunikasi dalam menyampaikan pesan kepada sasarannya. Saat ini meskipun masih berkomunikasi secara langsung, tokoh masyarakat memanfaatkan WhatsApp sebagai media komunikasi dalam menyampaikan pesan, informasi yang disampaikan menjadi lebih efektif dan merupakan kepuasan tersendiri karena menggunakan teknologi informasi (WhatsApp) pesan lebih cepat 
diterima kepada sasaran. Isi pesan; adalah; keamanan lingkungan, ikatan sosial, pendidikan, kesejahteraan dan pekerjaan serta hiburan $^{(8)}$

Aplikasi WhatsApp ini memiliki kecanggihan yang semua orang mampu menggunakanya dengan mudah, sederhana, aman, reliable, kemudahan untuk menelpon dan biayanya lebih murah sehingga sangat disuskai oleh semua orang yang menggunakannya. Ketersedian aplikasi chat yang responsive dan sangat cepat diterima dan mudah serta cepat mendapatkan balasannya sehingga membuat aplikasi ini menjadi primadona bagi semua penggunanya sehinga dapat menjadi media komunikasi yang efektif antar orang atau individu ${ }^{(21)}$

Dalam pembinaan yang dilakukan saat diskusi dan sharing WhatsAppgrup, adanya antusiasme dari ibu-ibu bayi balita tersebut dalam mengikuti proses nya dilalui dengan banyak pertanyaan seputar pertumbuhan berat badan dan perubahan perkembangan kebutuhan bayi serta pentingnya deteksi dini atas kelainan atau komplikasi yang ditemukan pada bayi balita mereka. Termasuk cara pembuatan MP-ASI sebagai kebutuhan tambahan saat bayi mengalami delayed growth atau faltering growth pada usianya sekarang.

Hasil pengamatan terhadap dua orang bayi yang mengalami delayed growth atau faltering growth adalah adanya perubahan signifikan terhadap perubahan berat badan dan panjang badan bayi sehingga ibu dan keluarga merasa sangat terbantu dan mampu mencegah kejadian stunting secar lebih awal, dengan pelaksanaan kujungan offline ke klinik bidan untuk mendapatkan gambaran penambahan berat badan dan panjang badan, serta ketepatan penambahan berat badan melalui rancangan menu yang sudah dijelaskan serta cara pemberian susu formula (sufor sebagai bantuan agar berat badan dan panjang badannya naik)

Selama pemantauan tidak terdapat kendala berarti karena kedua orangtua merasa puas dan mengaku seakan mendapat perhatian penuh dari tenaga kesehatan, hal ini disebabkan kemudahan mendapatkan informasi dan penjelasan secara tertulis dan lisan pesan suara (voice note) dari bidan sehingga mereka mudah memahami informasi dan penjelasan tersebut, dimana ini adalah sebagai bentuk manfaat dari aplikasi online WhatsApp yang mereka rasakan dalam membantu memantau proses perkembangan anaknya. Terjadi direct communiacation dengan metode dua arah dan timbal balik, sehingga semua pertanyaan ibu terjawab dengan baik.

\section{Kesimpulan}

Berdasarkan hasil pelaksanaan kegiatan pengabdian masyarakat yang dilakukan pada kelompok bayi balita ditemukan pengetahuan ibu bayi balita bertambah selama pembinaan baik saat pelayanan secara offline tatap muka langsung maupun online dalam grup WA, dan pemantauan $\mathrm{BB}$ pada bayi yang bermasalah mengalami perubahan 
signifikan dalam 4 minggu pemantauan.

Diharapkan semua orangtua bayi dan balita menjadi lebih mandiri, kreatif dan inovatif dalam memutuskan penggunaan smartphone dengan bijak yang dimanfaatkan untuk kepentingan kesehatan bayi dan balita mereka.

\section{Daftar Pustaka}

[1]. Keuangan K. Kementerian (2018), Keuangan Penanganan Stunting Terpadu Tahun 2018. [Online] http://www.anggaran.depkeu. go.id/content/Publikasi/stunti ng/PenangananStunting_DJA .pdf

[2]. Islah W. Perilaku Perawatan Luka Perinium, Pola Hidup Sehat dan Kondisi Partum memberikan kontribusi kesakitan dan kematian Ini menunjukkan infeksi postpartum pada ibu merupakan komplikasi yang dapat terjadi dari Wabah pandemic Covid-19 yang berkembang saat ini s. J Kebidanan Harapan Ibu Pekalongan; vol.7, no.2, pp. 65-78, 2020.

[3]. Wahyuni I, Hasanah U, Yanti N, Putra ID. Pemberdayaan Ibu Pasca Bersalin, Keluarga, tentang PHBS, Perawatan Ibu dan Bayi serta Pencegahan Penularan COVID-19. J ABDIMASHIP; vol.1 no.2, pp.78-87, 2020.

[Online] http://akbidhipekalongan.ac.i $\mathrm{d} / \mathrm{e}-$ journal/index.php/abdimashi $\mathrm{p} /$ article/view/105
[4]. Santoso DH, Santosa A. Dalam Ragam Tinjauan, 2020.

[5]. Tjandrawinata R. Industri 4.0: Revolusi Industri Abad Ini dan Pengaruhnya pada Bidang Kesehatan Dan Bioteknologi; pp. 31-9, 2016. [Online] http://zenodo.org/record/494 04

[6]. Nugraha D. Transformasi Sistem 2019, September 2018.

[7]. Ristekdikti. Vol.8.I.2018 1. Media Pustak; 8: pp.1-56, 2018.

[8]. Trisnani -. Pemanfaatan Whatsapp Sebagai Media Komunikasi Dan Kepuasan Dalam Penyampaian Pesan Dikalangan Tokoh Masyarakat. J Komunika J Komunikasi, Media dan Inform; vol.6, no.3, 2017.

[9]. Yusmita M, Larisu Z, Saidin. Pemanfaatan WhatsApp Messenger Sebagai Media Komunikasi Antar Pribadi Mahasiswa Ilmu Komunikasi *Mei Yusmita ** Dr. Zulfiah Larisu, S.Sos, M.Si., *** Saidin, S.Ip, M.Si; pp.1-12, 2014.

[10]. Keputusan Menteri Kesehatan Republik Indonesia. Keputusan Menteri Kesehatan Republik Indonesia Nomor HK.01.07/MenKes/413/2020 Tentang Pedoman Pencegahan dan Pengendalian Corona Virus Disease 2019 (Covid-19). MenKes/413/2020, 2019. 
[11]. Riduwan A. Pelaksanaan Kegiatan Pengabdian Kepada Masyarakat Oleh Perguruan Tinggi. EKUITAS (Jurnal Ekon dan Keuangan); vol.3, no.2 p.95, 2016.

[12]. Spesialis Ilmu Kesehatan Anak. Gagal Tumbuh (Failure to Thrive $=$ Weight Faltering) pada. Fak Kedokt Univ Airlangga. pp. 60-75.

[13]. Catherine Aranda M, Spence SJ. Best Practices: Pediatrics. Autism Spectrum Disorders. pp. 1323-1336, 2013.

[14]. Zaidah L. Analisis Faktor Yang Mempengaruhi Delayed Development Pada Anak Usia 12-24 Bulan Di Rumah Sakit Yogyakarta. J Fisioter dan Rehabil. Universitas AY. vol. 4 no.1, pp. 54-63, 2020.

[15]. RI KK. Pedoman Bagi Ibu Hamil, Ibu Nifas, dan Bayi Baru Lahir selama Social Distancing. pp.9-12, 2020.

[16]. Sandra F, Ahmad S, Arinda V. Cegah Stunting itu Penting. War Kesmas. pp.127, 2018.

[17]. Wahyuni I. Optimalisasi Pembinaan Kelompok Bina Balita Pada Ibu Yang Memiliki Bayi Balita Tentang Masalah Pertumbuhan: Status Gizi, Stunting Pada Anak Usia $<2$ Tahun Di Wilayah Puskesmas Payung Sekaki Pekanbaru. J Character Educ Soc. vol.3, no.1, pp.45-55, 2020.

[18]. Purnomo H. Peran Orang Tua dalam Optimalisasi Tumbuh Kembang Anak untuk Membangun Karakter Anak Usia Dini. Pros Semin Nas Parent.pp.34-47, 2013.
[19]. Lau LL, Hung N, Go DJ, Ferma J, Choi M, Dodd W, et al. Knowledge, attitudes and practices of COVID-19 among income-poor households in the Philippines: A crosssectional study. J Glob Health. vol.10 no.1, 2020.

[20]. Bagi P, Hamil IBU Selama Social Distancing. p.11, 2020.

[21]. Rahartri. "Whatsapp" Media Komunikasi Efektif Masa Kini (Studi Kasus Pada Layanan Jasa Informasi Ilmiah di Kawasan Puspiptek). Visi Pustaka. vol.21, no.2, pp.147-56. [Online] https://ejournal.perpusnas.go. $\mathrm{id} / \mathrm{vp} /$ article/view/552https:// ejournal.perpusnas.go.id/vp/a rticle/view/552 
Dokumentasi :

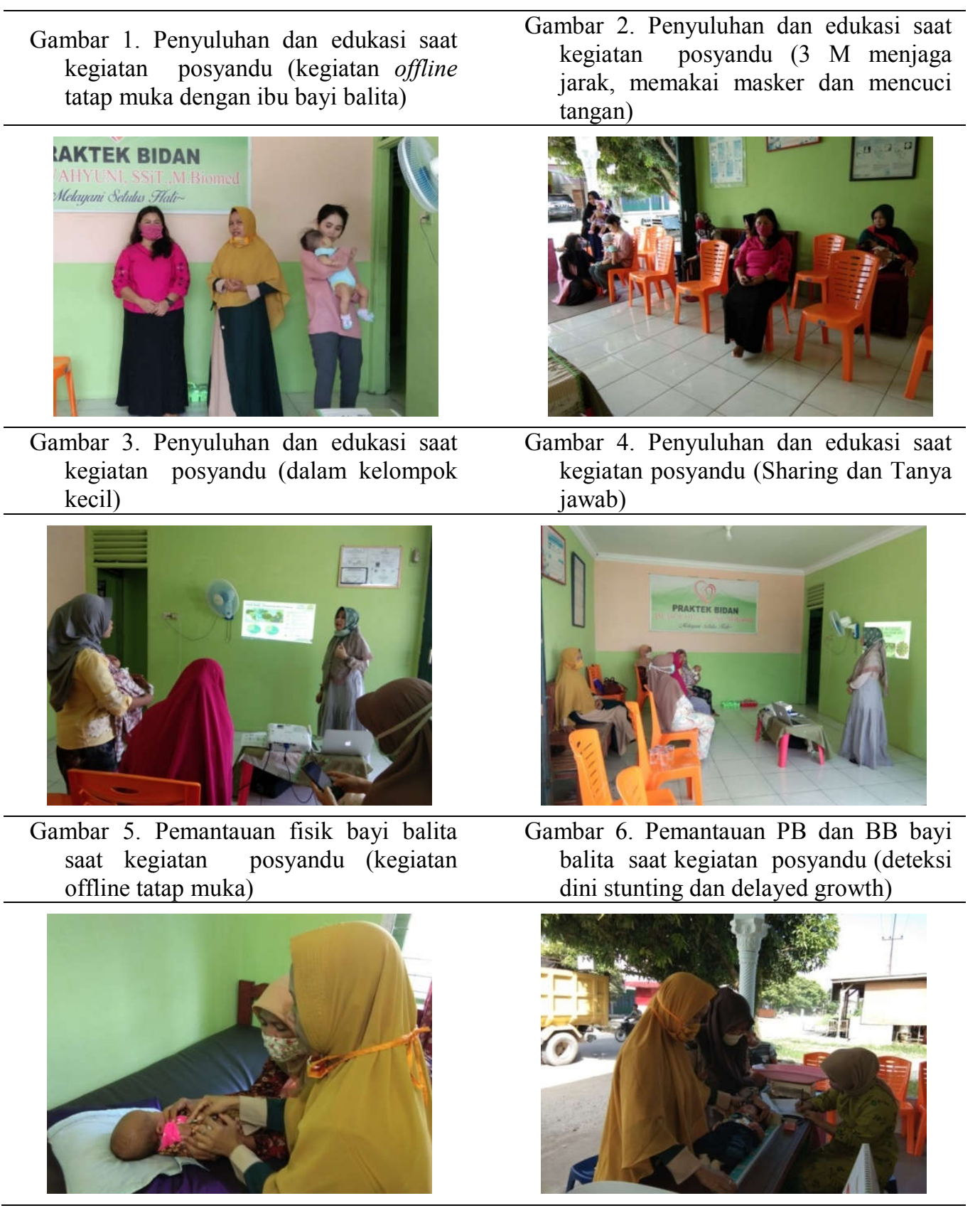




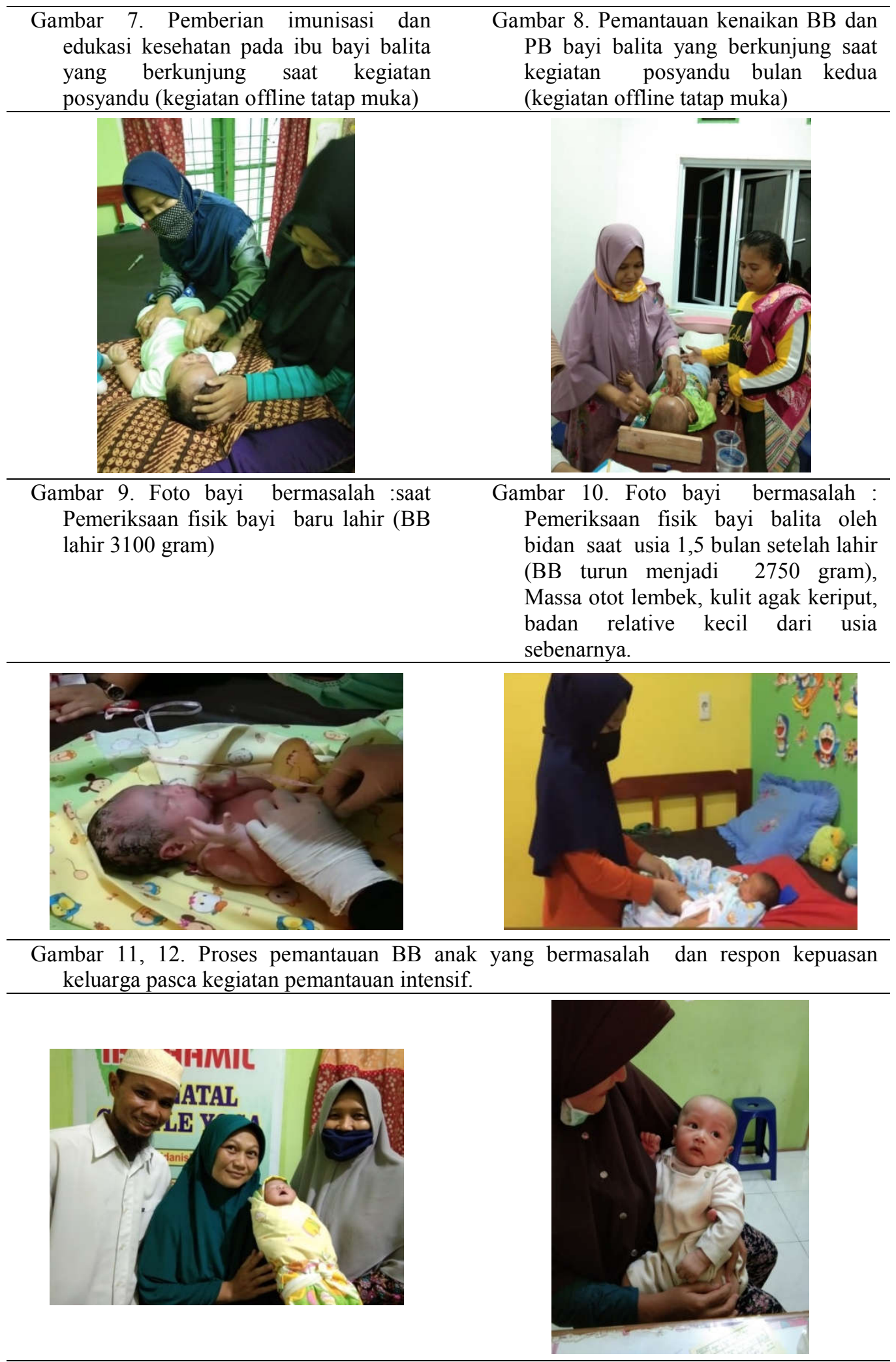




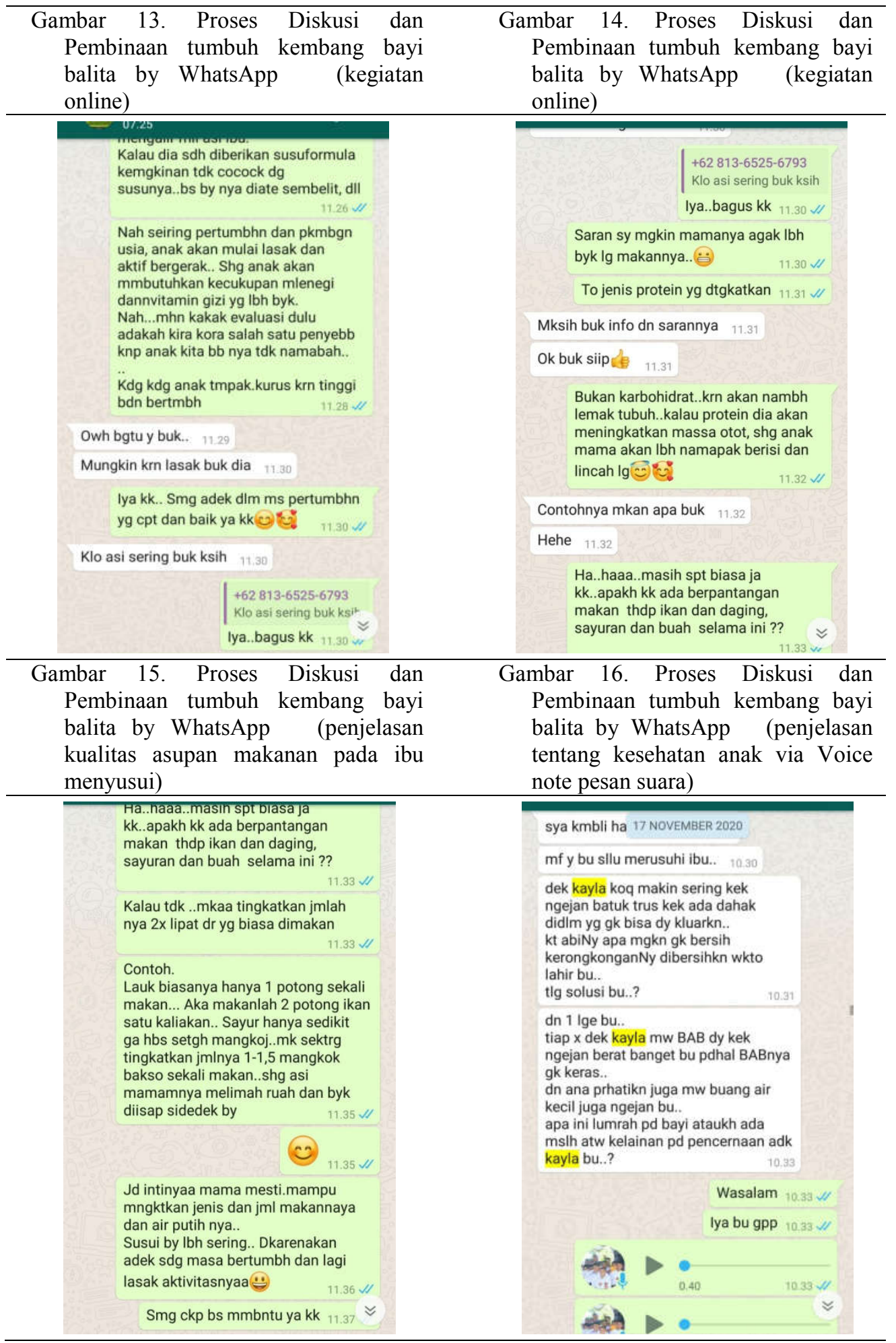

